\title{
COLONISATION OF POST-MINING RECULTIVATED AREA BY TERRESTRIAL ISOPODS (ISOPODA: ONISCOIDEA) AND CENTIPEDES (CHILOPODA) IN HUNGARY
}

\author{
J.J. PURGER ${ }^{1 *}-$ S. FARKAS ${ }^{2}-$ L. DÁNYI ${ }^{3}$ \\ ${ }^{1}$ Department of Animal Ecology, Institute of Biology, Faculty of Sciences, University of Pécs, H- \\ 7624 Pécs, Ifjúság útja 6, Hungary, Tel:++36-72-503-600 Fax:++36-72-503-634 \\ ${ }^{2}$ Ecological Research Group, Faculty of Animal Science, University of Kaposvár, H-7400 \\ Kaposvár, Guba S. 40, Hungary Tel:++36-82-314-155 Fax:++36-82-320-167 \\ ${ }^{3}$ Hungarian Academy of Sciences Research Group for Systematic Zoology, Hungarian Natural \\ History Museum, H-1088 Budapest, Baross Str. 13, Hungary Tel:++36-1-267-70-07/135 \\ Fax++36-1-267-58-88 \\ e-mail:purger@ttk.pte.hu \\ (Received $13^{\text {th }}$ March 2006 ; accepted $24^{\text {th }}$ Apr 2007)
}

\begin{abstract}
In the north-eastern outskirts of town Pécs (south Hungary) colonisation by terrestrial isopods and centipedes were studied in a post-mining recultivated area. During 4 months in 2002 a total of 140 pitfall traps that were positioned in the recultivated area, in the adjoining forest and in the forest edge yielded 289 specimens of 5 Isopoda species, and 250 specimens of 15 Chilopoda species. It is primarily the terrstrial isopod (Ligidium germanicum, Protracheoniscus amoenus, Trachelipus rathkii) and centipede (Lithobius erythrocephalus, L. forficatus, L. mutabilis, L. muticus, L. parietum) species living in the neighbouring forest that visited the recultivated area. Nevertheless, in the seventh year after recultivation, these were not valued as stable terrestrial isopod or centiped communities because of the low specimen and species numbers, and due to the irregularity of their occurrence.
\end{abstract}

Keywords. colonisation, recultivated area, Isopoda, Oniscoidea, Chilopoda, Hungary.

\section{Introduction}

In Europe, ecosystems on mine-sites represent a rare example of de novo ecosystem development. As expected, it has been found that the biocoenosis of ecosystems on mine-sites does not function entirely differently from comparable ecosystems on adjacent unmined sites. Major differences occur on sites with extreme substrate conditions. However, when these extreme sites are ameliorated chemically and rehabilitated with forest trees, pedogenesis and biocoenosis could be viewed as pointing towards normal development that occurs in comparable but unmined forest areas [12]. Soil-dwelling animals have an outstanding role in colonization and succession processes. The effect of feeding by many species of the soil fauna is to accelerate the decomposition processes as a result of comminution (reduction in organic particle size) or predation [11]. Terrestrial isopod species as decomposers and centipedes as carnivorous organisms appear as early as in the initial stage of colonization $[3,4,22]$.

We wanted to find out about the chances of terrestrial isopods and centipedes for settling in the recultivated, forest-fringed recultivated area in the initial years after recultivation and tree-planting. Would the first colonizers be forest-dwellers? Would the settlers be stable colonizers, maybe even communities, or just wandering individuals temporarily sallying outside the forest? 


\section{Methods}

The study was performed in the north-eastern outskirts of town Pécs (south Hungary) in the post-mining recultivated area bordered from the west by the eastern slopes of Misina (535 $\mathrm{m}$ height above s.1.), the southernmost summit of Mecsek Hills. The northern part of the Karolina open-cast coal-mine, covering approximately 15 hectares is recultivated (Fig. 1.). Various tree saplings have been planted since 1996, but the covering layer is overgrown by herbaceous vegetation of the initial stage of primary succession $[17,18]$. The recultivated area is bordered from the east, north and west by Turkey Oak forests (Potentillo micranthae-Quercetum daleschampii Horvát A.O. 1981).

The pitfall traps were laid out along four transect lines, $120 \mathrm{~m}$ long each, in a way that the sample plots overlap with forest as well as with the reultivated area as much as possible. In each of the transect lines 7 plots, spaced $20 \mathrm{~m}$ apart, were set up, and 5 pitfall traps installed in each (Fig. 1.), yielding a total of 140 pitfall stations. In the individual trap stations, the $300 \mathrm{~cm}^{3}$ plastic cups (of $8 \mathrm{~cm}$ diameter and $11 \mathrm{~cm}$ depth) were positioned to form a $0.5 \mathrm{~m}$ radius circle, with 4 vessels placed along the perimeter and one in the centre (Fig. 1.). The cups contained a 7:2:1 ratio mixture of water, 20\% acetic acid, and ethylene-glycol. Traps were left to function from $7^{\text {th }}$ May to $7^{\text {th }}$ September 2002. During this time they were checked and emptied 8 times, i.e. at $15.12 \pm 3.76$ (mean \pm sd) day intervals. Because of the low number of terrestrial isopods and centipedes, data resulting from the four transects were merged (Table 1.).

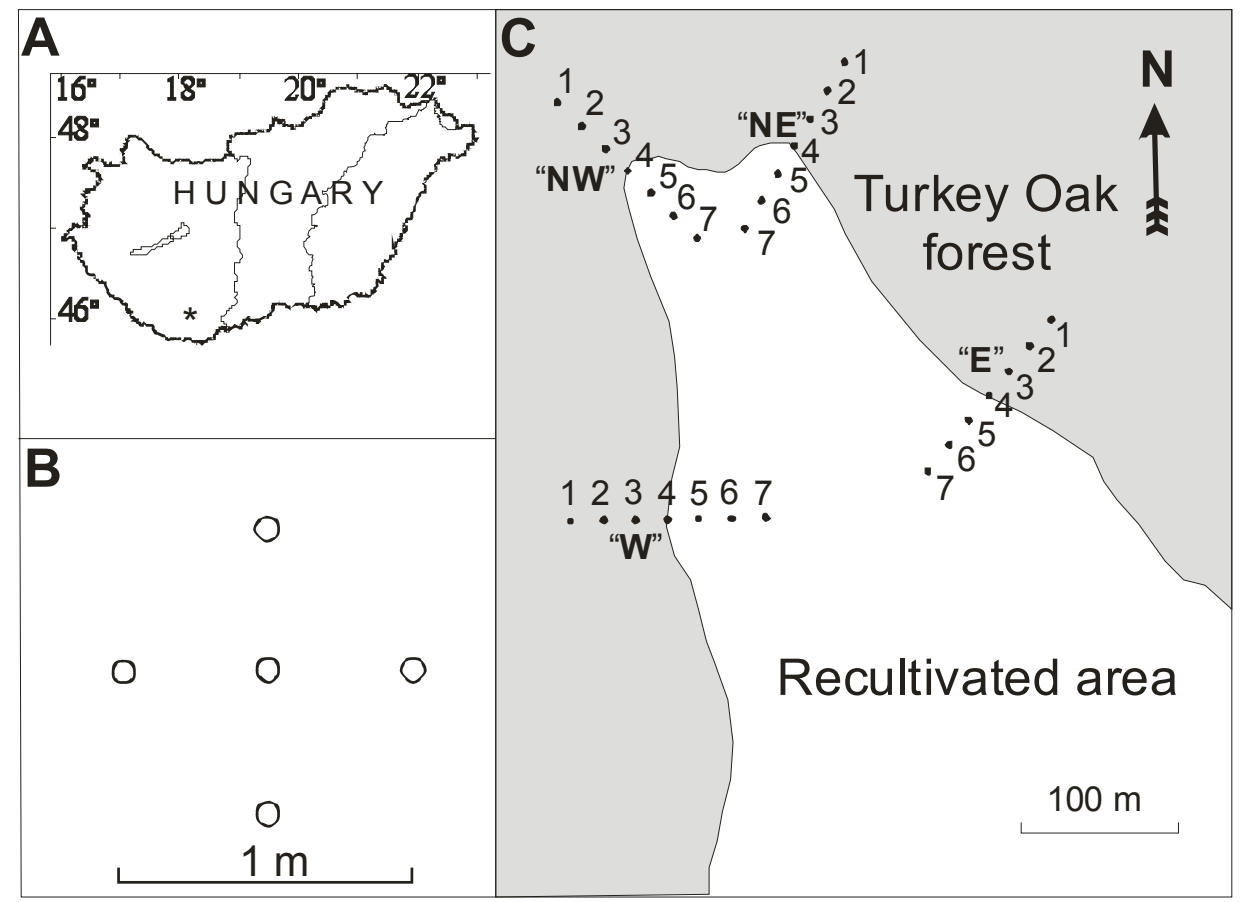

Figure 1. Location of the study area $\left(^{*}\right)$ within Hungary (A); pattern of pitfall traps within trap plots $(B)$; the arrangement of trap plots along the four transect lines $(W-$ western, $N W-$ northwestern, NE-north-eastern, E-eastern) (C). 
Table 1. Capture data in the 7 trapping plots. The naming and listing order of terrestrial isopods and chilopods is according to SCHMALFUSS [19] and DÁNYI [1].

\begin{tabular}{|c|c|c|c|c|c|c|c|c|}
\hline Habitat & \multicolumn{3}{|c|}{ Turkey Oak forest } & \multirow{2}{*}{$\begin{array}{c}\text { Edge } \\
4\end{array}$} & \multicolumn{3}{|c|}{ Recultivated area } & \multirow{2}{*}{$\begin{array}{r}\text { Total } \\
7 \\
\end{array}$} \\
\hline Trap plots No. & 1 & 2 & 3 & & 5 & 6 & 7 & \\
\hline \multicolumn{9}{|l|}{ Isopoda } \\
\hline Ligidium germanicum & 0 & 1 & 1 & 12 & 1 & 0 & 0 & 15 \\
\hline Lepidoniscus minutus & 0 & 0 & 1 & 0 & 0 & 0 & 0 & 1 \\
\hline Porcellium collicola & 0 & 1 & 0 & 0 & 0 & 0 & 0 & 1 \\
\hline Protracheoniscus politus & 34 & 85 & 65 & 23 & 0 & 1 & 0 & 208 \\
\hline Trachelipus rathkii & 16 & 17 & 8 & 21 & 1 & 1 & 0 & 64 \\
\hline Total & 50 & 104 & 75 & 56 & 2 & 2 & 0 & 289 \\
\hline \multicolumn{9}{|l|}{ Chilopoda } \\
\hline Lithobius agilis & 0 & 0 & 2 & 1 & 0 & 0 & 0 & 3 \\
\hline Lithobius dentatus & 2 & 3 & 3 & 0 & 0 & 0 & 0 & 8 \\
\hline Lithobius erythrocephalus & 1 & 0 & 1 & 3 & 3 & 2 & 0 & 10 \\
\hline Lithobius forficatus & 8 & 10 & 12 & 16 & 1 & 2 & 1 & 50 \\
\hline Lithobius melanops & 0 & 0 & 0 & 1 & 0 & 0 & 0 & 1 \\
\hline Lithobius mutabilis & 1 & 1 & 1 & 6 & 1 & 1 & 0 & 11 \\
\hline Lithobius muticus & 20 & 39 & 19 & 27 & 1 & 0 & 0 & 106 \\
\hline Lithobius nodulipes & 0 & 1 & 0 & 0 & 0 & 0 & 0 & 1 \\
\hline Lithobius parietum & 3 & 2 & 4 & 7 & 1 & 1 & 0 & 18 \\
\hline Lithobius sp. & 6 & 3 & 1 & 5 & 0 & 0 & 0 & 15 \\
\hline Eupolybothrus transsylvanicus & 2 & 2 & 5 & 8 & 0 & 0 & 0 & 17 \\
\hline Eupolybothrus tridentinus & 0 & 0 & 0 & 1 & 0 & 0 & 0 & 1 \\
\hline Cryptops anomalans & 1 & 0 & 2 & 3 & 0 & 0 & 0 & 6 \\
\hline Cryptops parisi & 0 & 0 & 1 & 0 & 0 & 0 & 0 & 1 \\
\hline Strigamia acuminata & 1 & 0 & 0 & 0 & 0 & 0 & 0 & 1 \\
\hline Strigamia transsilvanica & 0 & 0 & 1 & 0 & 0 & 0 & 0 & 1 \\
\hline Total & 45 & 61 & 52 & 78 & 7 & 6 & 1 & 250 \\
\hline
\end{tabular}

\section{Results and Discussion}

The number of terrestrial isopod (289) and centipede (250) specimens caught by the 140 traps was similar $\left(\chi^{2}=2.82\right.$, df $=1$, NS) (Table 1.). The low number of the decomposer arthropods was due to the infavourable habitat conditions and the low effectiveness of traps. The relatively high number of carnivorous arthropods, on the other hand, could be caused by the fact that these organisms prey also on other species in addition to terrestrial isopods, and therefore can reach higher species and specimen numbers. The number of centiped species (15) was three times higher than that of terrestrial isopod species (5).

The number of terrestrial isopods caught inside the forest and in the forest edge (1-4) were significantly different $\left(\chi^{2}=24.85\right.$, df $\left.=3, \mathrm{P}<0.001\right)$ (Table 1.). Difference between the effectiveness of traps in various plots may be due to the sloping of the area (descending from plot 1 towards plot 4), and to the uneven distribution of leaf litter on the ground. The comparison of specimen numbers of centipedes in the four plots was, also, different $\left(\chi^{2}=10.34, \mathrm{df}=3, \mathrm{P}<0.05\right)$ (Table 1.). These carnivorous arthropods 
seemed to prefer the edge zone. Traps positioned inside the recultivated area (plots 5-7) yielded only $1.4 \%$ of total captured terrestrial isopods and only $5.6 \%$ of total captured centipedes.

There are 32 terrestrial isopod species known to occur in Mecsek Hills [6, 7, Farkas and Vilisics, unpublished data], of which only $5(15.6 \%)$ were recorded in our study area. In the recultivated area, however, it was possible to capture only those speces that were found to be common inside the forest (P. politus, $T$. rathkii) or in the forest edge (L. germanicum). Single specimens of $L$. minutus and $P$. collicola, respectively, were revealed from traps inside the forest.

There are 28 centipede species known to occur in Mecsek Hills [2], of which 15 (53.6\%) were recorded in our study area. Lithobius muticus was found to be the commonest $(42 \%)$, yet only one specimen occurred in the recultivated area. Individuals of the second commonest (20\%) species (L. forficatus), however, made it to even the furthest parts of the recultivated area (Table 1.) Beside these species, only 5 specimens of L. erythrocephalus, 2 L. mutabilis and 2 L. parietum were collected in the recultivated area (Table 1.). Although Eupolybothrus transsylvanicus was found only in the forest and the forest edge, this species deserves special attention, because it has not been collected in Mecsek Hills since the studies by Loksa [13] [2].

Our results suggest that the terrestrial isopod T. rathkii and the centipede L. forficatus may be one of the first colonizer species not only in mine areas [3, 4, 22, 23], but also in recultivated areas. Initial settler species, however, might not come from the nearby forest only. Individuals belonging to species that tolerate less favourable habitat conditions may also appear. This assumption is supported by the fact that in a survey made in 2003 yet another terrestrial isopod (Trachelipus nodulosus) was revealed (our unpublished data). T. nodulosus occurs primarily in warm and dry habitats; in Mecsek Hills it is a dominant species of south-facing karst shrubby forests [14].

In the recultivation of spoil banks in Visonta (Hungary), plant coverages of up 100 percent were observed by the second year [21]. Similarly, rapid vegetation sucession was observed in the northern recultivated area of Karolina-pit [18], but this was not followed by an immediate colonization by terrestrial isopod and centiped species. Due to their poor quality, low nutritive value and high silicate content, the monocotyledon plants dominating the recultivated area are much less suitable for terrestrial isopods than the high quality food patches of dicotyledonous leaf litter $[9,10]$ found inside the forest. Moreover, predation pressure (by centipedes, spiders, carabid beetles, amphibians, reptiles, birds and small mammals) is probably stronger in the exposed area with poorer leaf litter cover [16]. Increase in plant-species diversity or structural diversity are often correlated with an increase in species richness of animals [20]. The recultivated area was not favourable for centipedes either. Grgić and Kos [8] investigated the influence of forest development phase on centipede diversity and found the highest species number and abundance in the juvenile phase and the lowest in the deforested area. Also the composition of the centipede community was more sensitive to the successional status of the forest than to the season [8]. In the seventh year after the recultivation of the study area there is no stable terrestrial isopod or centipede community, as concluded from the low species and specimen numbers, and the irregular occurrences. In order for the colonization process to be succesfully followed $[5,15]$ and for the date of successful completion of recultivation to be estimated, long-term monitoring is essential. 
Acknowledgements. We would like to thank P. TESZLÁK and B. TRÓCSÁNYI for collaboration. The field study was supported by PANNONPOWER Inc. and by the 2.2 and 2.5 subprograms of the NKFP 3/050/2001 R+D scheme.

\section{REFERENCES}

[1] Dányi, L. (2004): Centipedes (Chilopoda) of Hungary. - In Stloukal, E., Kalúz, S. (eds.) Book of Abstracts: Fauna Carpathica Meeting 2004. Faunima, Bratislava.

[2] Dányi, L. (2005): Zur Chilopoden-Fauna des Mecsek-Gebirges in Südwest-Ungarn. Schubartiana 1: 17-26.

[3] Dunger, W. (1989): The return of soil fauna to coal mined areas in the German Democratic Republic. - In Majer, J.D. (ed.) Animals in Primary Succession - The Role of Fauna in Reclaimed Lands. Cambridge University Press.

[4] Dunger, W., Voigtländer, K. (1989): Succession of Miriapoda in primary colonization of reclaimed land. - In Minelli, A. (ed.) Progress of 7th International Congress of Myriapodology. Brill, Leiden,

[5] Dunger, W., Wanner, M., Hauser, H., Hohberg, K., Schulz, H.-J., Schwalbe, T., Seifert, B., Vogel, J., Voigtländer, K., Zimdars, B., Zulka, K.P. (2001): Development of soil fauna at mine sites during 46 years after afforestation. - Pedobiologia 45: 243-471.

[6] Farkas, S. (2004a): Data to the knowledge of the terrestrial Isopod fauna of the Mecsek Mountains, South Hungary (Isopoda: Oniscidae). - Folia comloensis 13: 69-78.

[7] Farkas, S. (2004b): First record of Proporcellio vulcanius (Verhoeff, 1908) $(=P$. quadriseriatus) (Isopoda, Oniscidea: Porcellionidae) from Hungary. - Acta Phytopathol. Entomol. Hung. 39: 399-404.

[8] Grgić, T., Kos, I. (2005): Influence of forest development phase on centipede diversity in managed beech forests in Slovenia. - Biodivers. Conserv. 14: 1841-1862.

[9] Hassall, M. (1996): Spatial variation in favourability of a grass heath as habitat for woodlice (Isopoda: Oniscidea). - Pedobiologia 40: 514-528.

[10] Hassall, M., Tuck, J.M., Smith, D.W., Gilroy, J.J., Addison, R.K. (2002): Effects of spatial heterogeneity on feeding behaviour of Porcellio scaber (Isopoda: Oniscidea). Eur. J. Soil Biol. 38: 53-57.

[11] Hutson, B.R. (1989): The role of fauna in nutrient turnover. - In Majer, J.D. (ed.) Animals in Primary Succession - The Role of Fauna in Reclaimed Lands. Cambridge University Press.

[12] Hüttl, R.F., Bradshaw, A. (2001): Ecology of Post-Mining Landscapes. - Restor. Ecol. 9: 339-340.

[13] Loksa, I. (1955): Über die Lithobiiden des Faunagebietes des Karpatenbeckens. - Acta Zool. Hung. 1: 331-349.

[14] Loksa, I. (1966): Die bodenzoozönologischen Verhältnisse der FlaumeichenBuschwälder Südostmitteleuropas. - Akadémiai Kiadó, Budapest.

[15] Neumann, U. (1971): Die Successionn der Bodenfauna (Carabidae, Coleoptera, Diplopoda und Isopoda) in den forstlich rekultivierten Gebieten des Rheinischen Braunkohlenreviers. - Pedobiologia 11: 193-226.

[16] Paoletti, M.G., Hassall, M. (1999): Woodlice (Isopoda: Oniscidea): their potential for assessing sustainability and use as bioindicaors. - Agr. Ecosyst. Environ. 74: 157-165.

[17] Purger, J.J., Mészáros, L.A., Purger, D. (2004a): Predation on artificial nests in postmining recultivated area and forest edge: contrasting the use of plasticine and quail eggs. - Ecol. Eng. 22: 209-212.

[18] Purger, J.J., Mészáros, L.A., Purger, D. (2004b): Ground nesting in recultivated forest habitats - a study with artificial nests. - Acta Ornithol. 39: 140-145.

[19] Schmalfuss, H. (2003): World catalog of terrestrial isopods (Isopoda: Oniscidea). Stuttg. Beitr. Naturk. (Ser. A) 654: 1-341. 
[20] Southwood, T.R.E., Brown, V.K., Reader, P.M. (1979): The relationships of plant and insect diversities in succession. - Biol. J. Linn. Soc. 12: 327-348.

[21] Szegi, J., Oláh, J., Fekete, G., Halász, T., Várallyay, G., Bartha, S. (1988): Recultivation of the Spoil Banks Created by Open-Cut Mining Activities in Hungary. - AMBIO 17: 137-143.

[22] Tajovský, K. (2001): Colonization of Colliery Spoil Heaps by Millipedes (Diplopoda) and Terrestrial Isopods (Oniscidae) in the Sokolov Region, Czech Republic. - Restor. Ecol. 9: 365-369.

[23] Topp, W., Simon, M., Kautz, G., Dworschak, U., Nicolini, F., Prückner, S. (2001): Soil fauna of a reclaimed lignite open-cast mine of the Rhineland: improvement of soil qualiti by surface pattern. - Ecol. Eng. 17: 307-322. 